\title{
Evaluation of hydronephrotic kidney parenchymal density by non-contrast multislice computed tomography
}

\author{
Hidronefrotik böbrek parankim dansitesinin kontrastsız çok kesitli bilgisayarlı tomografi kullanılarak değerlendirilmesi
}

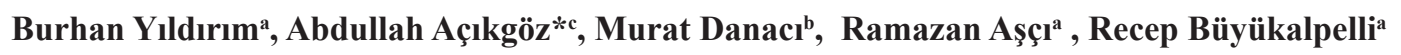

${ }^{a}$ Department of Urology, Medical Faculty, Ondokuz Mayls University, Samsun, Turkey

${ }^{b}$ Department of Radiology, Medical Faculty, Ondokuz Mayls University, Samsun, Turkey

${ }^{c}$ Department of Urology, Gazi State Hospital, Samsun, Turkey

\begin{tabular}{|c|c|}
\hline \multicolumn{2}{|c|}{ ARTICLE INFO } \\
\hline \multicolumn{2}{|c|}{ Article History } \\
\hline Received & $21 / 02 / 2012$ \\
\hline Accepted & 17 / 03 / 2012 \\
\hline
\end{tabular}

* Correspondence to:

Abdullah Açıkgöz

Department of Urology,

Gazi State Hospital,

İlkadım, Samsun, Turkey

e-mail: draacikgoz@yahoo.com

\section{Keywords:}

Complete ureteral obstruction

Partial ureteral obstruction

Multislice computed tomography

Renal parenchymal density

Urinary stone disease

Hounsfield unit

\author{
Anahtar Kelimeler: \\ Tam üreteral obstrüksiyon \\ Parsiyel ureteral obstrüksiyon \\ Çok kesitli bilgisayarlı tomografi \\ Böbrek parankim dansitesi \\ Üriner sistem taş hastalığı \\ Hounsfield ünitesi
}

\section{ABSTRACT}

It is well known that a prolonged ureteral obstruction leads to function loss of the congested kidney. Determining whether kidney stones cause any obstruction by noncontrast multislice CT is crucial for deciding about the timing of treatment. In our study we evaluated by Non-Contrast Multislice Computed Tomography (NCMSCT) detectable reliable changes of the density of the renal parenchyma in rats with artificial hydronephrosis. We made total or partial obstruction to left ureters of Spraque-Dawley rats, and applied sham operation to control groups. Using NCMSCT we measured the renal average parenchyma densities in the first, third and thirteenth days of operation. There was no significant difference between the parenchyma density of partial obstructed group and control group. However the parenchyma density in totally obsructed kidneys has significantly decreased compared to the contralateral kidneys and control group. In this group the duration of the obstruction correlated with significantly decreased parenchyma density. The average density values of the upper, middle and lower renal segments were similar. We assume that our results can be useful in the evaluation of the consequences of the ureteral obstruction. The decrease of the parenchyma density evaluated in NCMSCT could be an important indicator of the renal parenchymal damages.

J. Exp. Clin. Med., 2012; 29:215-220

\section{ÖZET}

Uzun süren üreteral obstrüksiyonun böbrek fonksiyon kaybına neden olduğu iyi bilinmektedir. Üriner sistem taşına bağlı herhangi bir obstrüksiyonun kontrastsız çok kesitli bilgisayarlı tomografi (KÇKBT) ile belirlenmesi tedavi zamanlaması hakkında karar vermek açısından çok önemlidir. Çalişmamızda deneysel hidronefroz oluşturulan ratlarda renal parankim dansitesinde meydana gelen değişiklikler KÇKBT ile değerlendirildi. $\mathrm{Bu}$ çalışmada sol üreterlerinde total veya parsiyel obstrüksiyon oluşturulmuş SpraqueDawley ratların böbrek parankim dansiteleri deneyin 1.,3. ve 30. günlerinde KÇKBT ile değerlendirilerek, sham ve kontrol grubu ratların böbrek parankim dansiteleri ile karşılaştırıldı. Parsiyel üreteral obstrüksiyon oluşturulmuş ratların böbrek parankim dansiteleri ile kontrol grubunun böbrek parankim dansiteleri arasında anlamlı bir fark olmadığ 1 saptandı. Bununla birlikte total üreteral obstrüksiyon oluşturulmuş ratların böbrek parankim dansitelerinin karşı taraf böbrekleri ve kontrol grubu ile karşılaştırıldığında anlamlı olarak azaldığı saptandı. Böbrek üst, orta ve alt segmentlerinin ortalama dansite değerleri benzerdi. Elde edilen bu bulguların insanlarda üreter obstrüksiyonun sonuçlarının değerlendirilmesinde yararlı olabileceğini düşünmekteyiz. KÇKBT değerlendirilmesinde renal parankim dansitesinin azalması renal parankimal hasarın bir göstergesi olabilir. J. Exp. Clin. Med., 2012; 29:215-220 


\section{Introduction}

Hydronephrosis resulting from an obstruction of the ureter, commonly encountered in urological practice, may cause progressive injury in renal parenchyma and lead to permanent loss of renal function if not treated (Vaughan et al., 1971; Ito et al., 2004). Urinary tract obstruction can develop in different age groups for different reasons. Ureteropelvic junction obstruction in infants and children, urinary tract stone disease in young and adults, and hydronephrosis associated with malignant disease in older population, are very common (Vaughan et al., 1971).

Nowadays, with the developments in radiological imaging methods, ureteral obstructions can be diagnosed easily. Ultrasonography is a simple, fast, and non-invasive imaging method. It provides a large amount of anatomical information but fails in screening ureters to explain the causes of hydronephrosis. Intravenous urography (IVU), which was widely used in the past, has some disadvantages. For example, IVU requires a contrast agent and cannot be applied for patients with kidney failure, and the results take longer (Smith et al., 1995).

As a result of technical developments in computed tomography (CT), urinary tract examination is now faster and images are sharper. Renal parenchyma, collecting tubules and opaque and non-opaque stones can be easily imaged with the use of CT (Smith et al., 1995; Tublin et al., 2002). The reported $95-100 \%$ and $97-100 \%$ sensitivity and specificity values of non-contrast multislice CT (NCMSCT) for the detection of ureteral stones in patients with suspected renal colic demonstrate the superiority of NCMSCT over IVU and ultrasonography (Smith et al., 1995). Nevertheless, CT does not provide information about renal function and the duration of the obstruction. The possibility that NCMSCT examination not only detects the urinary tract stones but also the changes in the urinary tract is considered important.

With the recent advances in CT technology, tissue density differences can be detected more easily and quickly. When the CT images of the patients with urinary tract stone disease and hydronephrosis were analyzed retrospectively, it was observed that the parenchymal density of the affected kidney was significantly lower than that of the other kidney (Georgiades et al., 2001; Goldman et al., 2004; Ozer et al., 2004). But there was no information about the duration and type of obstruction (partial or complete).

Changes in the acute and chronic phase in renal paranchymal density in rats with unilateral complete and partial ureteral obstruction were compared with those in other kidney and sham-operated groups to investigate whether ureteral stones detected on NCMSCT cause obstruction, or whether they can be detected with the same method.

\section{Materials and methods}

This research was conducted by Ondokuz Mayıs University, Medical Faculty Department of Urology, at the Faculty of Medicine Surgical Research and Application Center with the contributions of the Department of Radiology.

The study was approved by the Experimental and Clinical Research Committee and the Local Ethical Committee. Thirty adult Sprague-Dawley rats of either sex weighing 200-300 g were used in the study. The rats were raised in the Surgical Research Center and fed with standard food and drinking water and kept in the same room in a 12/12 lightdark cycle. Each experimental group consisted of ten rats. Experimental groups:

Group 1: Sham-operated group

Group 2: Partial ureteral obstruction group

Group 3: Complete ureteral obstruction group

\section{Surgical procedures}

All rats were administered with $100 \mathrm{mg} / \mathrm{kg}$ sefazolin sodium intraperitoneally for surgical prophylaxis before the operation. After the induction of anaesthesia by intraperitoneal injection of ketamine hydrochloride $(50 \mathrm{mg} / \mathrm{kg})$, abdominal skin was shaved and cleaned with povidine iodine solution. An abdominal midline incision was made, and the intestines were deviated medially; the left kidney and left ureter were exposed. A partial ureteral obstruction was created according to the technique by Ulm and Miller (1962). The left ureter was freed from surrounding tissues. After placing the left ureter into an incision in the psoas muscle, the psoas muscles were closed in a single layer with $6 / 0$ polypropylene suture (Prolen, Ethicon). The left ureter was tied up with $4 / 0$ silk suture to create a complete ureteral obstruction. The sham operation was performed by releasing the left ureter. The anterior abdominal wall was closed with $4 / 0$ silk sutures.

\section{Computed tomography imaging}

Before the surgical procedures, the rat kidneys were scanned with multislice computed tomography for congenital or acquired anomalies. The renal images were obtained using a multislice CT device (Toshiba TSX-101A Aquilon 16 Tokyo/ Japan) on the 1st, 3rd and 30th postoperative days.

The rats were anesthetized with a dose of $50 \mathrm{mg} / \mathrm{kg}$ of ketamine before being scanned. The CT scans were acquired with a slice thickness of $3 \mathrm{~mm}(120 \mathrm{kV} 80 \mathrm{~mA})$ and slice intervals of $1 \mathrm{~mm}$. Following that, axial CT images with a slice thickness of $1 \mathrm{~mm}$ were generated. $4.9 \mathrm{~mm}$ measurement points (ROI) from the upper middle and lower poles of both kidneys were determined. Hounsfield Unit (HU) density measurements were performed (Figures 1,3).

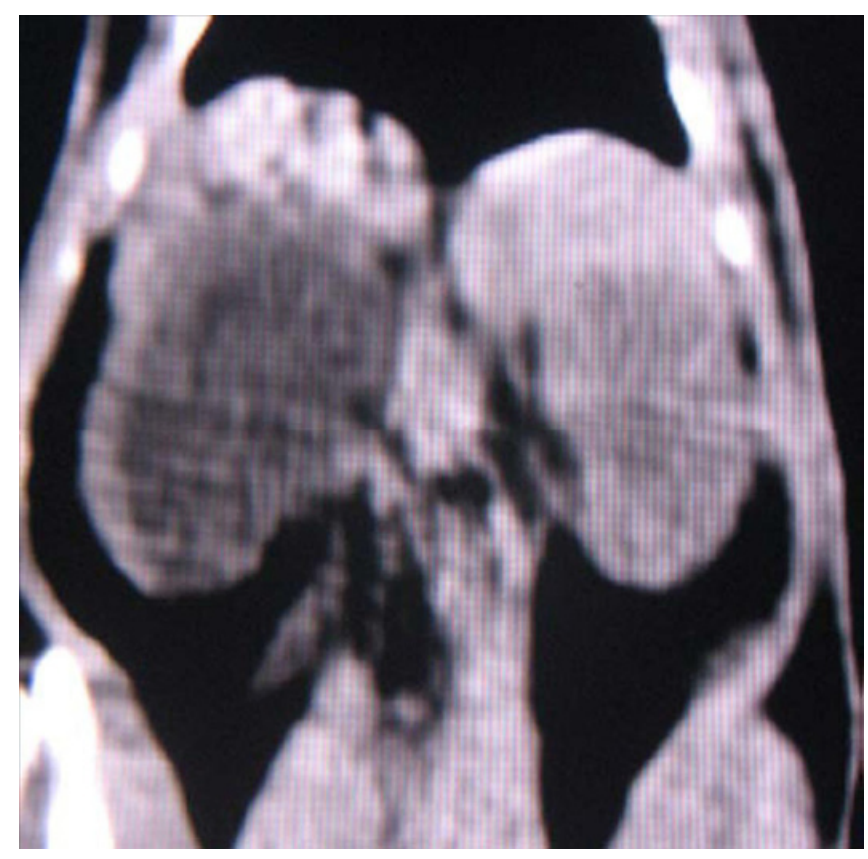

Fig. 1. Measurement of parenchymal density 


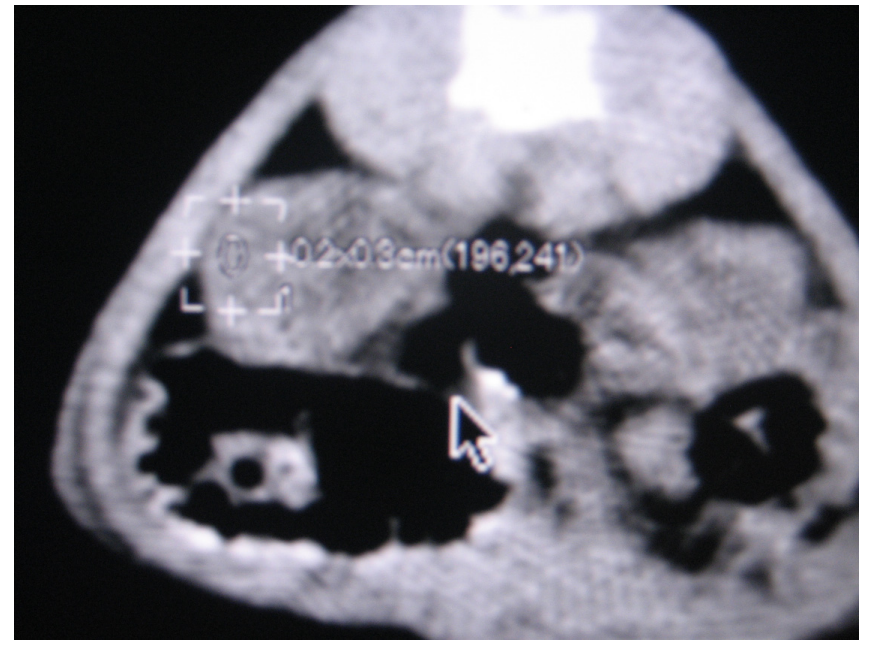

Fig. 2. Group 3 on the $30^{\text {th }}$ day's coronal image

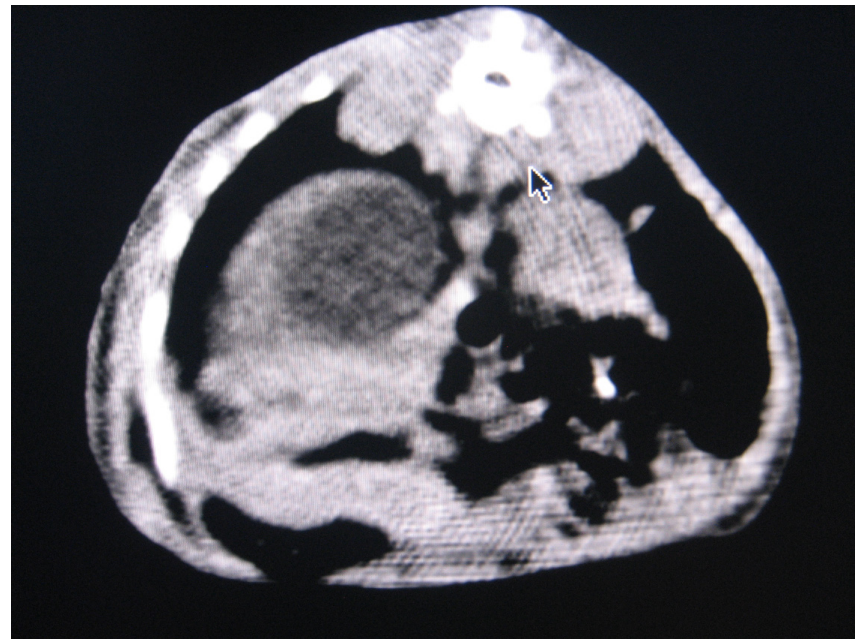

Fig. 3. Group 3 on the $30^{\text {th }}$ day's image

Hounsfield Unit measurements were obtained from relatively smaller regions in those with thinner renal parenchyma.

\section{Statistical analysis}

The mean values of each group were presented as an average $( \pm \mathrm{SD})$. Repeated measurement analysis of variance was used in the evaluation of the differences between the means of ingroup measurements. Student t-test, enabling group homogeneity and equality of variance, was used for the comparisons of the two groups. The renal paranchymal thickness values of partial and complete obstruction-operated groups were compared using One-way Analysis of Variance (ANOVA). The SPSS (Version 10.0) package program was used for statistical analysis.

\section{Results}

In the NCMSCT of rats in the sham-operated group, no signi-

Table 1. Average values of renal parenchyma densities of rats
in Group 1

\begin{tabular}{|c|c|c|c|c|}
\hline Measurement time & Left kidney* & Right kidney ** & t & p \\
\hline Beginning & $66.2 \pm 2.3$ & $66.3 \pm 1.8$ & 0.1 & $>0.05$ \\
\hline 1. Day & $67.8 \pm 1.6$ & $68.1 \pm 1.1$ & 0.5 & $>0.05$ \\
\hline 3. Day & $67.8 \pm 1.0$ & $67.6 \pm 1.1$ & 0.4 & $>0.05$ \\
\hline 30. Day & $67.4 \pm 0.8$ & $67.2 \pm 1.0$ & 0.6 & $>0.05$ \\
\hline
\end{tabular}

$* \mathrm{~F}=2.2 ; \mathrm{p}>0.05$

$* * \mathrm{~F}=3.0 ; \mathrm{p}>0.05$

\begin{tabular}{|c|c|c|c|c|}
\hline Measurement time & $\begin{array}{c}\text { Partial } \\
\text { Obstruction } \\
\text { (Left)* }\end{array}$ & $\begin{array}{l}\text { Healthy Kidney } \\
\text { (Right)** }\end{array}$ & $\mathbf{t}$ & $\mathbf{p}$ \\
\hline Beginning & $66.3 \pm 4.7$ & $68.5 \pm 4.2$ & 1.1 & $>0.05$ \\
\hline 1. Day & $66.2 \pm 4.6$ & $68.9 \pm 2.6$ & 1.6 & $>0.05$ \\
\hline 3. Day & $58.2 \pm 8.4$ & $58.8 \pm 8.9$ & 0.1 & $>0.05$ \\
\hline 30. Day & $65.9 \pm 7.2$ & $69.2 \pm 3.4$ & 1.3 & $>0.05$ \\
\hline $\begin{array}{l}* \mathrm{~F}=3.6 ; \mathrm{p}>0.05 \\
* * \mathrm{~F}=8.2 ; \mathrm{p}>0.05\end{array}$ & & & & \\
\hline
\end{tabular}

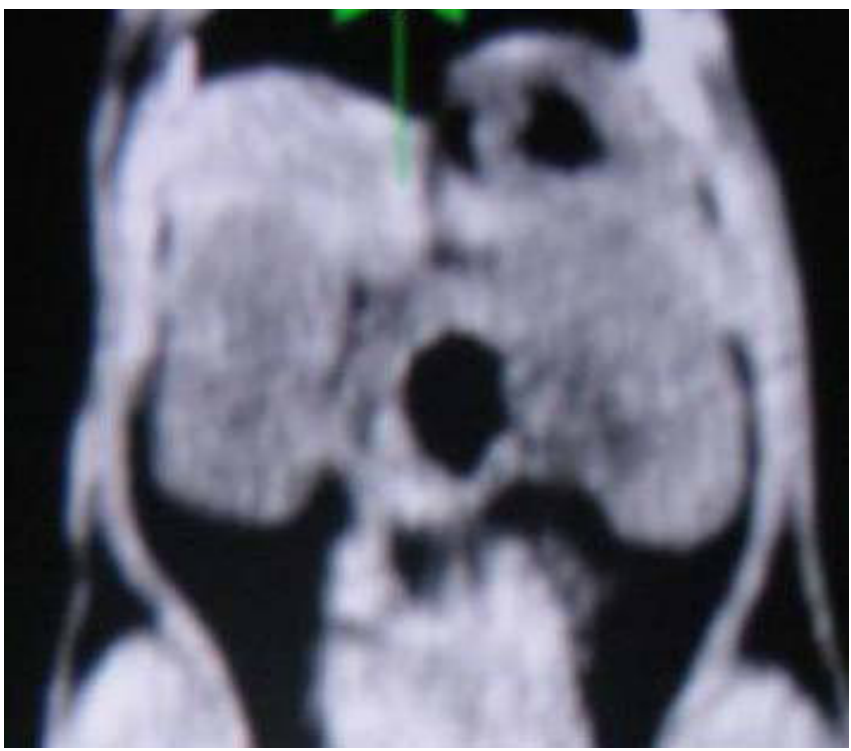

Fig. 4. Group 2 on the $30^{\text {th }}$ day's coronal image

ficant difference was observed between the mean Hounsfield Units (HU) on the 1st, 3rd and 30th days $(\mathrm{p}<0.05)$ (Table 1).

In the NCMSCT scans of rats with partial ureteral obstruction, no significant difference was observed between the Hounsfield Unit measurements of all renal parenchyma ( $>0.05$ ) (Table 2) (Fig. 4).

When the mean HU of obstructed renal parenchyma was compared with that of a healthy kidney on the NCMSCT scans of rats with complete ureteral obstruction, it was revealed that the density of the obstructed kidney decreased steadily from the 1st day, and a statistically significant difference was observed between them $(\mathrm{p}<0.001)$ (Table 3$)$.

When the renal parenchymal densities of rats in the Group 1 and the Group 3 were compared, there was an increasing decrease in both kidneys (particularly in obstructed-kidney) in comparison with the control group $(\mathrm{p}<0.001)$ (Tables 4 and 5).

A statistically significant difference was observed only on the $3 \mathrm{rd}$ day of the study in the paired comparison of the mean

\begin{tabular}{|c|c|c|c|c|}
\hline Measurement time & $\begin{array}{c}\text { Obstructed } \\
\text { kidney } \\
\text { (Left)* }\end{array}$ & $\begin{array}{l}\text { Healthy kidney } \\
\text { (Right)** }\end{array}$ & $\mathbf{t}$ & $\mathbf{p}$ \\
\hline Beginning & $68.3 \pm 3.5$ & $67.8 \pm 3.1$ & 0.3 & $>0.05$ \\
\hline 1. Day & $58.9 \pm 4.8$ & $64.1 \pm 2.1$ & 3.1 & $<0.01$ \\
\hline 3. Day & $55.5 \pm 3.8$ & $65.4 \pm 3.1$ & 6.4 & $<0.01$ \\
\hline 30. Day & $32.8 \pm 3.8$ & $49.3 \pm 3.4$ & 11.7 & $<0.01$ \\
\hline
\end{tabular}


Table 4. Paired comparison of left kidney parenchyma densities of the rats in Group 1 and Group 3

\begin{tabular}{ccccc} 
Measurement time & Group 1 & Group 3 & t & p \\
\hline Beginning & $66.2 \pm 2.3$ & $68.3 \pm 3.5$ & 1.6 & $>0.05$ \\
1. Day & $67.8 \pm 1.6$ & $58.9 \pm 4.8$ & 5.5 & $<0.01$ \\
3. Day & $67.8 \pm 1.0$ & $55.5 \pm 3.8$ & 10.0 & $<0.01$ \\
30. Day & $67.4 \pm 0.8$ & $32.8 \pm 3.8$ & 37.0 & $<0.01$ \\
\hline
\end{tabular}

Table 5. Paired comparison of right kidney parenchyma densities of the rats in Group 1 and Group 3

\begin{tabular}{lcccc} 
Measurement time & Group 1 & Group 3 & t & p \\
\hline Beginning & $66.3 \pm 1.8$ & $67.8 \pm 3.1$ & 1.4 & $>0.05$ \\
1. Day & $68.1 \pm 1.1$ & $64.1 \pm 2.1$ & 5.3 & $<0.001$ \\
3. Day & $67.6 \pm 1.1$ & $65.4 \pm 3.1$ & 2.1 & $>0.05$ \\
30. Day & $67.2 \pm 1.0$ & $49.3 \pm 3.4$ & 15.9 & $<0.001$ \\
\hline
\end{tabular}

left parenchymal densities of rats in Group 1 and Group 2 $(\mathrm{p}<0.01)$ (Table 6).

A statistically significant difference was observed on the 1st and 30th postoperative days in the paired comparison of the mean left parenchymal densities of rats in Group 2 and group $3(\mathrm{p}<0.001)$ (Table 7).

Table 6. Paired comparison of parenchyma density values of left kidney of the rats in Group 1 and Group 2

\begin{tabular}{ccccc} 
Measurement time & Group 1 & Group 2 & t & p \\
\hline Beginning & $66.2 \pm 2.3$ & $66.3 \pm 4.7$ & 0.09 & $>0.05$ \\
1. Day & $67.8 \pm 1.6$ & $66.2 \pm 4.6$ & 1.0 & $>0.05$ \\
3. Day & $67.8 \pm 1.0$ & $58.2 \pm 8.4$ & 3.6 & $<0.01$ \\
30. Day & $67.4 \pm 0.8$ & $65.9 \pm 7.2$ & 0.67 & $>0.05$ \\
\hline
\end{tabular}

In the evaluation of the upper, middle and lower poles of both kidneys of rats in Group 3 (complete ureteral obstruction group), a statistically significant difference was observed in accordance with the overall average $(\mathrm{p}<0.001)$ (Table 8$)$.

Measurements from the upper, middle and lower poles

Table 7. Paired comparison of parenchyma density values of left kidney of the rats in Group 2 and Group 3

\begin{tabular}{lcccc}
\hline Measurement time & Group 2 & Group 3 & t & p \\
\hline Beginning & $66.3 \pm 4.7$ & $68.3 \pm 3.5$ & 1.0 & $>0.05$ \\
1. Day & $66.2 \pm 4.6$ & $58.9 \pm 4.8$ & 3.5 & $<0.01$ \\
3. Day & $58.2 \pm 8.4$ & $55.5 \pm 3.8$ & 0.95 & $>0.05$ \\
30. Day & $65.9 \pm 7.2$ & $32.8 \pm 3.8$ & 13.5 & $<0.001$ \\
\hline
\end{tabular}

of the obstructed kidneys of rats in the complete ureteral operated-group were evaluated. Accordingly, no statistically significant difference was observed between upper, middle and lower poles' densities ( $\mathrm{p}>0.05)$ (Table 9).

\begin{tabular}{|c|c|c|c|c|c|}
\hline & Upper left & Middle left & Lower left & $\mathbf{F}$ & $\mathbf{p}$ \\
\hline Beginning & $67.5 \pm 3.8$ & $70.1 \pm 3.6$ & $67.1 \pm 5.6$ & 5.6 & $>0.05$ \\
\hline 1. Day & $60.3 \pm 5.3$ & $56.9 \pm 7.6$ & $59.6 \pm 5.6$ & 4.2 & $>0.05$ \\
\hline 3. Day & $56.9 \pm 5.3$ & $54.7 \pm 5.2$ & $54.8 \pm 4.3$ & 2.4 & $>0.05$ \\
\hline 30. Day & $33.7 \pm 4.2$ & $32.9 \pm 4.9$ & $31.9 \pm 3.3$ & 0.6 & $>0.05$ \\
\hline
\end{tabular}

\section{Discussion}

As it may cause progressive injury and lead to permanent loss in renal function, hydronephrosis resulting from the obstruction of the ureter is a pathology that needs early diagnosis and treatment. Urinary tract stone disease is one of the common causes of acute ureteral obstruction. With the use of NCMSCT in the diagnosis of urinary tract stone disease, especially nonopaque stones can be identified more easily and accurately (Smith et al., 1995; Tublin et al., 2002). Besides providing information about the size, localization and chemical structure of stones, NCMSCT can also display both urinary and non-urinary tract pathologies (Levine et al., 1997; Saw et al., 2000). The main disadvantage of using a NCMSCT in patients with urinary tract stone disease is that it exposes patients to a relatively high radiation due to the use of X-rays. As the use of NCMSCT expanded, the duration of obstruction and the level of renal function loss in a hydronephrotic kidney has become a research subject. Certainly, other imaging methods give us information about the degree of obstruction and renal functions. However those require additional examinations. Diagnosis of urinary system stones may be made and also duration and severity of obstruction and renal functions may easily be assessed through making parenchymal density measurement without the need of additional examinations, radiation or cost with NCMSCT that is routinely performed for diagnosing urinary system stones in every clinic.

In a study investigating the differences in renal parenchyma density due to obstruction in patients with urinary tract stone disease with NCMSCT, the mean parenchymal densities of obstructed and non-obstructed kidneys were evaluated retrospectively (Georgiades et al., 2001). The mean parenchymal densities of the obstructed kidneys were lower than those of non-obstructed and those found in healthy people. The mean parenchymal density in normal kidneys was $32.2 \mathrm{HU}$, whereas it was $38 \mathrm{HU}$ in normal kidneys (Georgiades et al., 2001). Similarly, the results of another retrospective study re-

Table 8. Change of parenchyma densities measured from upper, middle, and lower poles of kidneys of the rats in Group 3 according to the days of the study

\begin{tabular}{|c|c|c|c|c|c|c|}
\hline & Beginning & 1.Day & 3.Day & 30. Day & $\mathbf{F}$ & $\mathbf{p}$ \\
\hline Upper left & $67.5 \pm 3.8$ & $60.3 \pm 5.3$ & $56.9 \pm 5.3$ & $33.7 \pm 4.2$ & 112.5 & $<0.001$ \\
\hline Middle left & $70.1 \pm 3.6$ & $56.9 \pm 7.6$ & $54.7 \pm 5.2$ & $32.9 \pm 4.9$ & 94.9 & $<0.001$ \\
\hline Lower left & $67.1 \pm 5.6$ & $59.6 \pm 5.6$ & $54.8 \pm 4.3$ & $31.9 \pm 3.3$ & 99.9 & $<0.001$ \\
\hline Upper right & $67.3 \pm 2.4$ & $65.8 \pm 2.7$ & $68.3 \pm 3.2$ & $47.5 \pm 3.8$ & 105.5 & $<0.001$ \\
\hline Middle right & $68.4 \pm 4.0$ & $62.3 \pm 3.6$ & $63.3 \pm 4.1$ & $50.8 \pm 4.3$ & 31.3 & $<0.001$ \\
\hline Lower right & $67.7 \pm 3.8$ & $64.1 \pm 4.2$ & $64.5 \pm 3.6$ & $49.5 \pm 4.6$ & 44.1 & $<0.001$ \\
\hline
\end{tabular}


vealed that the mean parenchymal density of obstructed kidneys was significantly lower than that of other kidneys: 32.6 HU in normal kidneys and 27.2 HU in obstructed kidneys (Goldman et al., 2004). As these are retrospective studies, we cannot establish the relationship between the duration of ureteral obstruction and the degree of changes in parenchyma. It is well known that there is a linear relationship between the duration of the obstruction and loss of renal function (Vaughan et al., 1971; Claesson et al., 1989; Ito et al., 2004). On the other hand, all the ureteral stones do not cause obstructions. The importance of early diagnosis and treatment of ureteral stones that cause obstruction is clear. Our study results showed that in complete obstructions, the parenchymal density of the obstructed kidney decreased, and this decrease increased over time (Table 3 ).

In partial obstructions, the parenchymal density decreased slightly in comparison with the initial value, but it showed a tendency to increase the old values. The mean parenchymal density of the partially-obstructed kidney was $66.3 \mathrm{HU}, 58.2$ HU and 65.9 HU on the 1st, 3rd and 30th days of the study, respectively. Similarly, the mean parenchymal density of the healthy kidney was $68.5 \mathrm{HU}, 58.28 \mathrm{HU}$ and $69.2 \mathrm{HU}$ on the 1 st, 3rd and 30th of the study, respectively. No statistically significant difference was observed between the renal parenchymal densities ( $p>0.05)$. In the comparisons of the parenchymal density of the left kidneys in rats in this group with the sham-operated group, a statistically significant difference was observed only on the 30th day of the study $(p<0.05)$, and this difference disappeared on the 30 th day $(p>0.05)$. We think that this was due to edema caused by the surgery in the early phase of partial ureteral obstruction.

In the literature, there are many studies investigating the effects of chronic partial ureteral obstruction on kidneys. The effects of partial ureteral obstruction, the most common form of ureteral obstruction in clinic, were investigated by the use of an experimental model in accordance with the technique described by Ulm and Miller (1962). But many studies using the same model have revealed different results. Some differences such as fibrosis in the renal pelvis and deformation in the renal papilla have been reported in the second week of partial unilateral ureteral obstruction (Claesson et al., 1983). On the contrary, dilatation, local inflammatory response and degeneration in collective and corrugated tubules are not remarkable. In the study, chronic inflammatory lesions such as interstitial lymphocyte infiltration and fibrosis in the renal pelvis and medulla were more frequent on the 6th and 9th week. At the end of a one year follow-up, the incidence of chronic interstitial inflammation, medullar edema, haemorrhage and micro cystic hyperplasia in pelvis epithelium had increased. The reason why there was no statically significant difference between the mean parenchymal densities of partially obstructed kidneys and those of other healthy kidneys is that histological changes in the partial unilateral ureteral obstruction become apparent on the 6th and 9th week, and that chronic changes arise in a longer process (Tublin et al., 2002). We suggest that there may be a decrease in the parenchymal density and a statistically significant difference in the case of having more than a 90 day follow-up in the partial obstruction group.

In the NCMSCT images of rats with complete ureteral obstruction in Group 3, the mean renal parenchymal HU of obstructed kidneys decreased gradually since the 1st day and there was a statistically significant difference $(p<0.01)$. While the initial mean parenchymal density of rats in this group was $68.3 \mathrm{HU}$, it was 58.9, 55.5 HU and $32.8 \mathrm{HU}$ on the 1st, 3rd and 30th days, respectively. Similarly, in a retrospective study, the mean parenchymal density of obstructed kidneys was 27.7 HU and 34.4 HU in non-obstructed kidneys (Ozer et al., 2004). In a complete obstruction, the pyelotubular backflow and edema are considered the causes of a decrease in the renal parenchymal density due to the intrapelvic pressure in NCMSCT (Georgiades et al., 2001). A statistically significant difference was observed between the paired comparisons of the renal densities of rats (left kidney operated) in Group 2 and Group 3 on the 1st and 30th days of the study $(\mathrm{p}<0.01$ and $\mathrm{p}<0.001$, respectively).

An interesting finding in our study is that the renal parenchymal density of the other kidney decreased in unilateral complete obstructions. While the mean renal parenchymal density of normal kidneys was calculated as $67.8 \mathrm{HU}$, it was $64 \mathrm{HU}, 65.4 \mathrm{HU}$ and $49.3 \mathrm{HU}$ on the 1st, 3rd and 30th day of the study, respectively. Compared with the initial values, a very small decrease in density was observed on the 1 st and 3rd day, but this decrease became significant on the 30th day.

We think that this is due to the compensatory changes in the other kidneys with a unilateral ureteral obstruction. Thus, a significant edema was observed in the renal cortex and medulla on the 3rd week of the study in rabbits with unilateral uretopelvic junction obstruction (Ekinci et al., 2003).

In our study, we aimed to investigate in which region of the kidney renal parenchymal density measurements will give accurate results. For this purpose, the density measurements of the upper, middle and lower poles were compared. The mean parenchymal densities of the left kidneys' upper, middle and lower poles were $67.5 \mathrm{HU}, 70.1 \mathrm{HU}$ and $67.1 \mathrm{HU}$, and these decreased to $33.7 \mathrm{HU}, 32.9 \mathrm{HU}$ and $31.9 \mathrm{HU}$ on the 30th days, respectively. Similarly, the mean parenchymal densities of the right kidneys' upper, middle and lower poles were $67.3 \mathrm{HU}, 68.4 \mathrm{HU}$ and $67.7 \mathrm{HU}$, and these decreased to 47.5 HU, 50.8 HU and 49.5 HU on the 30th days, respectively (Table 8 ). These findings revealed that there were no differences between the three different poles of both kidneys in terms of parenchymal density $(p<0.05)$, and the parencymal density measurements from the three different poles of the kidneys did not affect the results (Table 9).

On the other hand, as rats' kidneys are too small for such reviews, we failed to measure the renal cortex and medulla separately. The parenchymal density measurements of the renal cortex and medulla can be performed on animals which have larger kidneys.

It is well known that there is a relationship between the recovery of renal functions in urinary obstructions and the duration, and that the prolonged duration of obstruction causes an irreversible loss of renal function. In addition, urinary infection and internal pelvis structure speed up the damage (Vaughan Jr et al., 1971). In this experimental study, whether there was a relationship between stones detected with NCMSCT method performed for diagnosing urinary system stones in patients who were admitted to urology clinic with complaint of renal colic and early and late period parenchymal density changes in ipsilateral kidney and duration and severity of obs- 
truction was tried to be shown. There are no previous studies in literature about this topic. Parenchymal density changes of the kidney was clinically shown in retrospective studies and compared with the cases in which obstruction was detected however no information was given about the duration of the obstruction (Georgiades et al., 2001; Goldman et al., 2004; Ozer et al., 2004). This study was considered to be beneficial for assesment of surgical treatment or conservative follow up options in cases with renal colic. While early interventions in complete ureteral obstruction can protect the renal function, conservative treatment options can be used for the kidney stones that pass spontaneously.

It would be useful to add a new finding (decrease in parenchyma density) to the other associated findings, such as dilation in the renal pelvis, peripheral lymphedema, perinephric or periureteral scarring, and tissue ring sign of presence of urethral obstruction in the NCMSCT. With the use of the technique, it is possible to perform a density measurement without additional costs, processes or radiation. However, further studies are needed to determine the ranges of the parenchymal density of healthy kidneys of humans and changes in density in the case of complete ureteral obstruction.

\section{Conclusion}

We assume that our results can be useful in the evaluation of the consequences of ureteral obstruction. The decrease of the parenchyma density evaluated in NCMSCT could be an important indicator of the renal parenchymal damages. It is still not clear whether the quantification of decreased renal parenchyma density in the NCMSCT is a reliable parameter which could replace renal scintigraphy in clinical practice. In the next step we are planning a clinical trial with the aim to compare the changes of the renal parenchyma density in NCMSCT with the results of renal scintigraphia in patients with ureteral obstruction.

\section{REFERENCES}

Claesson, G., Josephson, S., Robertson, B., 1983. Experimental partial ureteric obstruction in newborn rats. IV. Do the morphological effects progress continuously? J. Urol. 130, 1217-1222.

Claesson, G., Svensson, L., Robertson, B., Josephson, S, Cederlund, T., 1989. Experimental obstructive hydronephrosis in newborn rats. XI. A one-year follow-up study of renal function and morphology. J. Urol. 142, 1602-1607.

Ekinci, S., Ciftci, A.O., Atilla, P., Muftuoglu, S., Senocak, M.E., Buyukpamukcu, N., 2003. Ureteropelvic junction obstruction causes histologic alterations in contralateral kidney. J. Pediatr. Surg. 38, 1650-1655.

Georgiades, C.S., Moore, C.J., Smith, D.P., 2001. Differences of renal parenchymal attenuation for acutely obstructed and unobstructed kidneys on unenhanced helical CT: A useful secondary sign? Am. J. Roentgenol. 176, 965-968.

Goldman, S.M., Faintuch, S., Ajzen, S.A., Christofalo, D.M, Araújo, M.P., Ortiz, V., Srougi, M., Kenney, P.J., Szejnfeld, J., 2004. Diagnostic value of attenuation measurements of the kidney on unenhanced helical CT of obstructive ureterolithiasis. Am. J. Roentgenol. 182, 12511254.

Ito, K., Chen, J., El Chaar, M., Stern, J.M., Seshan, S.V., Khodadadian, J.J., Richardson, I., Hyman, M.J., Vaughan, E.D., Jr Poppas, D.P., Felsen, D., 2004. Renal damage progresses despite improvement of renal function after relief of unilateral ureteral obstruction in adult rats. Am. J. Physiol. Renal. 287, 1283-1293.

Levine, J.A., Neitlich, J., Verga, M., Dalrymple, N., Smith, R.C., 1997. Ureteral calculi in patients with flank pain: Correlation of plain radiography with unenhanced helical CT. Radiology. 204, 27-31.

Ozer C., Yencilek, E., Apaydin, F.D., Duce, M.N., Yildiz, A., Erdem, E., Kanik, A., Cayan, S., 2004. Diagnostic value of renal parenchymal density difference on unenhanced helical computed tomography scan in acutely obstructing ureteral stone disease. Urology. 64, $223-226$.

Saw, K.C., McAteer, J.A., Monga, A.G., Chua, G.T., Lingeman, J.E., Williams, J.C. Jr., 2000. Helical CT of urinary calculi: Effect of stone composition, stone size, and scan collimation. Am. J. Roentgenol. 175, 329-332.

Smith, R.C., Rosenfield, A.T., Choe, K.A., Essenmacher, K.R., Verga, M., Glickman, M.G., Lange, R.C., 1995. Acute flank pain: Comparison of non-contrast-enhanced CT and intravenous urography. Radiology. 194, 789-794.

Tublin, M.E., Murphy, M.E., Delong, D.M., Tessler, F.N., Kliewer, M.A., 2002. Conspicuity of renal calculi at unenhanced CT: Effects of calculus composition and size and CT technique. Radiology. 225, 91-96.

Ulm, A.H., Miller, F., 1962. An operation to produce experimental reversible hydronephrosis in dogs. J. Urol. 88, 337-341.

Vaughan, E.D.Jr., Shenasky, J.H. 2nd., Gillenwater, J.Y., 1971. Mechanism of acute hemodynamic response to ureteral occlusion. Invest. Urol. 9, 109-118.

Vaughan, E.D.Jr., Sorenson, E.J., Gillenwater, J.Y., 1971. Alterations in renal function immediately after release of acute total unilateral ureteral occlusion. Invest. Urol. 8, 450-461. 